\title{
Procesowy model odnowy przedsiębiorstwa
}

\section{A process-based model of enterprise renewal}

Grzegorz Bełz, Jan Skalik

Uniwersytet Ekonomiczny we Wrocławiu,e-mails: grzegorz.belz@ue.wroc.pl,jan.skalik@ue.wroc.pl

\section{Streszczenie}

Trudności, jakie napotykają przedsiębiorstwa z dostosowywaniem się do coraz szybciej zmieniających się warunków otoczenia, pozostają jednym z kluczowych problemów menedżerskich. Celem artykułu jest przedstawienie koncepcji procesowego modelu odnowy przedsiębiorstwa oraz zaprezentowanie wyników analizy procesów odnowy.

Słowa kluczowe: odnowa przedsiębiorstw, proces transformacji, triumwirat zarządczy.

\begin{abstract}
Difficulties which enterprises encounter to adjust to faster and faster changing external conditions are one of the main managerial problems. The aim of the article is to show the concept of a process-based model of enterprises renewal and the results of renewal process analysis.
\end{abstract}

Keywords: renewal of enterprises, transformation process, management triumvirate. 


\section{Wstęp}

Umiejętność przeprowadzenia efektywnych procesów odnowy przedsiębiorstwa stanowi nieustające wyzwanie dla menedżerów. Sony, Nokia czy Kodak stanowią doskonałe przykłady, jak trudno było temu wyzwaniu sprostać. Równocześnie obecnie możemy obserwować poszerzający się poziom wyzwań dla takich firm, jak Microsoft, Google czy Apple. Ich działania w ciągu kilku najbliższych lat bądź to umożliwią utrzymanie dotychczasowych pozycji i przejście do „Ligi Mistrzów” przedsiębiorstw potrafiących dostarczać długofalowego sukcesu akcjonariuszom, bądź też doprowadzą do dołączenia przez nie do grona tych, które odeszły w cień.

Celem niniejszego artykułu jest przedstawienie koncepcji procesowego modelu odnowy przedsiębiorstwa oraz zaprezentowanie wyników analizy procesów odnowy w niemalże pięciuset firmach według tego modelu. Prezentowane wyniki badań stanowią element projektu badawczego „Odnowa polskich przedsiębiorstw” N N115 019939, finansowanego z środków na badania naukowe w latach 2010-2013.

$\mathrm{W}$ artykule w ramach przedstawienia podstaw teoretycznych prezentujemy omówienie zjawiska odnowy przedsiębiorstw oraz modeli opisujących kluczowe ich składowe. Prezentowane koncepcje i rozwiązania są wynikiem studiów międzynarodowej literatury przedmiotu i identyfikacji najistotniejszych koncepcji ostatnich lat. W następnej kolejności przedstawiamy koncepcję triumwiratu archetypowych ról menedżerskich oraz powiązania jej w procesowy model odnowy przedsiębiorstw. W ramach prezentacji wyników badań wskazujemy na możliwości interpretacji złożonych zjawisk odnowy z wykorzystaniem tegoż modelu.

\section{Zjawisko odnowy przedsiębiorstw}

Zjawisko odnowy przedsiębiorstw pozostaje w ostatnich dwóch dekadach przedmiotem intensywnych badań z zakresu nauk o zarządzaniu. Rozpowszechnione w zachodniej literaturze przedmiotu określenia odnowa przedsiębiorstwa (corporate renewal) oraz odnowa strategiczna (strategic renewal) są kolejnymi perspektywami badań nad zdolnością przedsiębiorstw do odnowy zapoczątkowanymi jeszcze w latach osiemdziesiątych XX wieku. Pojęcia te nie doczekały się dotychczas jednolitej, powszechnie uznawanej definicji. W badaniach realizowanych w ramach projektu „Odnowa organizacyjna polskich przedsiębiorstw” przyjęliśmy, iż, jako że odnowa przedsiębiorstwa jest zjawiskiem występującym na różnych poziomach, konieczne jest rozróżnienie co najmniej dwóch jej poziomów: strategicznego oraz organizacyjnego. Przyjęliśmy więc, że pierwszy z nich, opisujący strategiczne uwarunkowania odnowy, określany mianem strategicznej odnowy przedsiębiorstwa, należy rozumieć jako proces, treść i efekt wymiany kluczowych elementów modelu biznesowego [Bełz 2012]. Przytoczona definicja opiera na zaproponowanym przez G. Bełza powiązaniu kompleksowości rozumienia zjawiska odnowy w ujęciu R. Agarwal i C. Helfat z diagnostyczno-projektowym ujęciem strategicznego modelowania biznesu zapropo- nowanym przez A. Osterwaldera (zob. [Bełz, Olejczyk 2012]). Dwie pierwsze autorki zaproponowały, aby strategiczną odnowę przedsiębiorstwa rozumieć jako „proces, treść i efekt przekształcania lub wymiany tych cech organizacji, które posiadają znaczący wpływ na jej długofalowe perspektywy funkcjonowania" [Agarwal, Helfat 2009, s. 282]. Krytyczna analiza zaproponowanej definicji doprowadziła do propozycji dookreślenia „tych cech organizacji, które posiadają znaczący wpływ na jej długofalowe perspektywy funkcjonowania". G. Bełz w swych badaniach, obserwując przypadki odnowy przedsiębiorstw, zauważył, że zakres przekształceń tych strategicznych cech najlepiej jest opisywany współcześnie pojęciem modelu biznesu [Bełz 2011, s. 36]. Oparcie się na koncepcji modelu biznesu autorstwa A. Osterwaldera (zob. [Osterwalder, Pigneur 2010]) było wynikiem analizy dostępnych w literaturze przedmiotu propozycji definicyjnych i uznania, iż nie taksonomiczne, lecz diagnostyczno-projektowe ujęcie tego konceptu, osadzone w nurcie design science, posiada największą wartość zarówno poznawczą, jak i aplikacyjną.

Drugi ze wspomnianych poziomów odnowy określiliśmy mianem organizacyjnej odnowy przedsiębiorstwa. Zdefiniowaliśmy ją jako treść, proces i efekt przekształceń kluczowych elementów systemu zarządzania warunkowanych zmianami modelu biznesowego [Cyfert, Bełz, Wawrzynek 2014; s. 16]. Stanowi ona warunek skutecznej implementacji opisanej powyżej strategicznej odnowy przedsiębiorstwa. Dzieje się tak dlatego, iż realne przekształcenie modelu biznesowego przedsiębiorstwa możliwe jest jedynie poprzez ukształtowanie i wdrożenie nowego modelu organizacyjnego oraz przyjęcie oczekiwanych zachowań, a także pozyskanie kompetencji przez jego pracowników. Powiązania pomiędzy tymi strategicznymi i organizacyjnymi poziomami, wypracowane $\mathrm{w}$ ramach realizacji wspomnianego projektu badawczego, prezentuje rys. 1 .

W odniesieniu do powyższego, ważne jest zwrócenie uwagi na konieczność uwzględnienia w rozważaniach nad zjawiskiem odnowy przedsiębiorstw także samego procesu transformacji. Jak wynika z przytoczonej definicji, stanowi on, obok treści i efektu, istotę tego zjawiska. W przywołanym na rys. 1 modelu proces ten opisany jest $\mathrm{w}$ warstwie realizacji decydującej o możliwości implementacji zarówno strategicznej, jak i organizacyjnej odnowy przedsiębiorstwa. Istotne jest zwrócenie uwagi na systemowy aspekt takiego rozumienia procesów odnowy przedsiębiorstw. Poszczególne trzy warstwy modelu są ze sobą wzajemnie powiązane, warunkując się wzajemnie. Znaczenie warstwy realizacyjnej wynika nie tyle z implementacji nowego modelu biznesowego i modelu organizacji, ile także, a może przede wszystkim, ze znaczenia, jakie proces zmiany ma w samym kształtowaniu tych nowych modeli. Immamentnym elementem tego procesu jest bowiem tworzenie nowych wizji i modelu biznesowego, a także kształtowanie nowego modelu organizacyjnego i systemu zarządzania. Składowe procesu odnowy przedsiębiorstwa prezentuje rys. 2. 


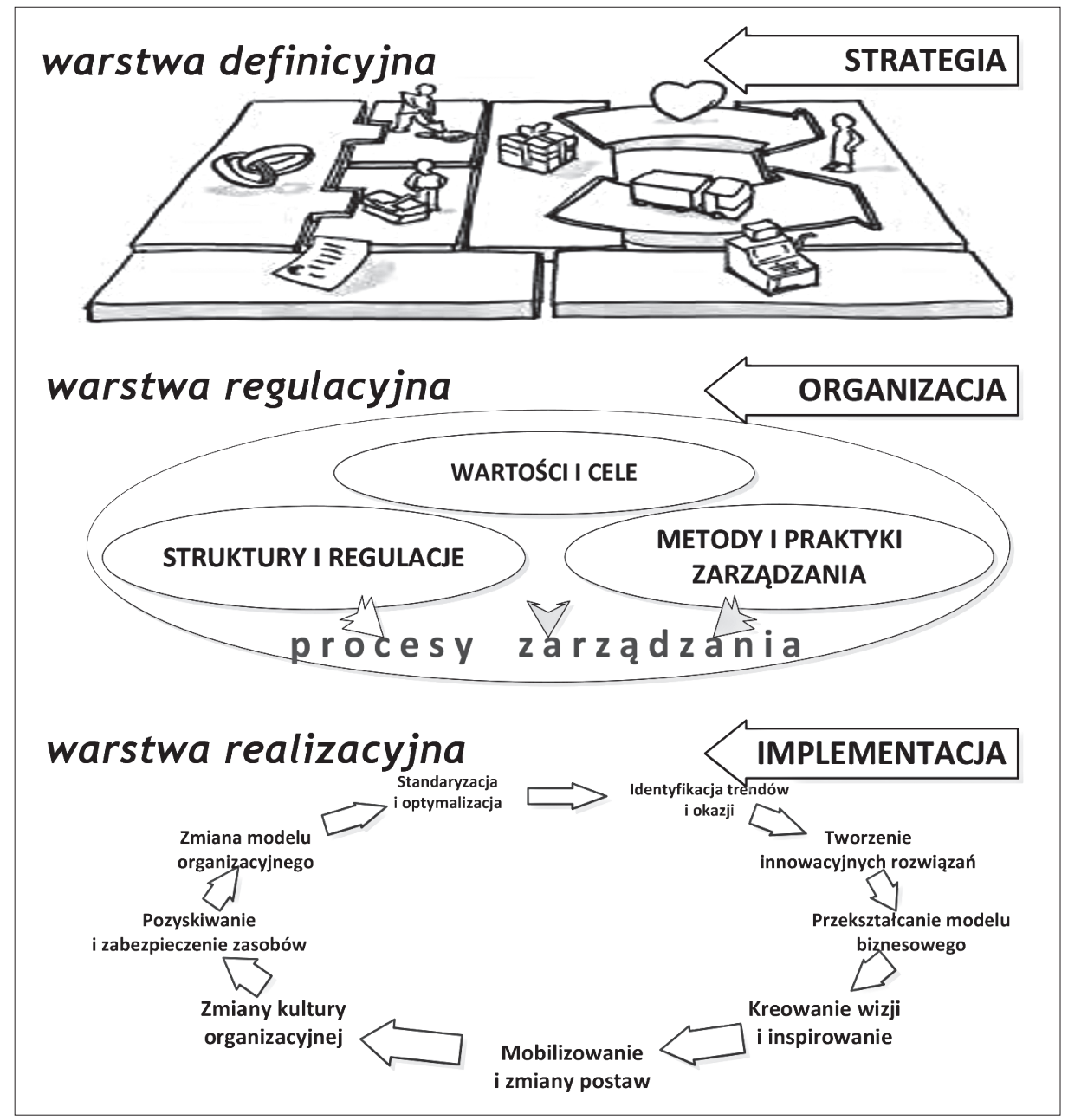

Rysunek 1. Systemowy model odnowy przedsiębiorstwa

Źródło: opracowanie własne na podstawie [Cyfert 2012, s. 125].

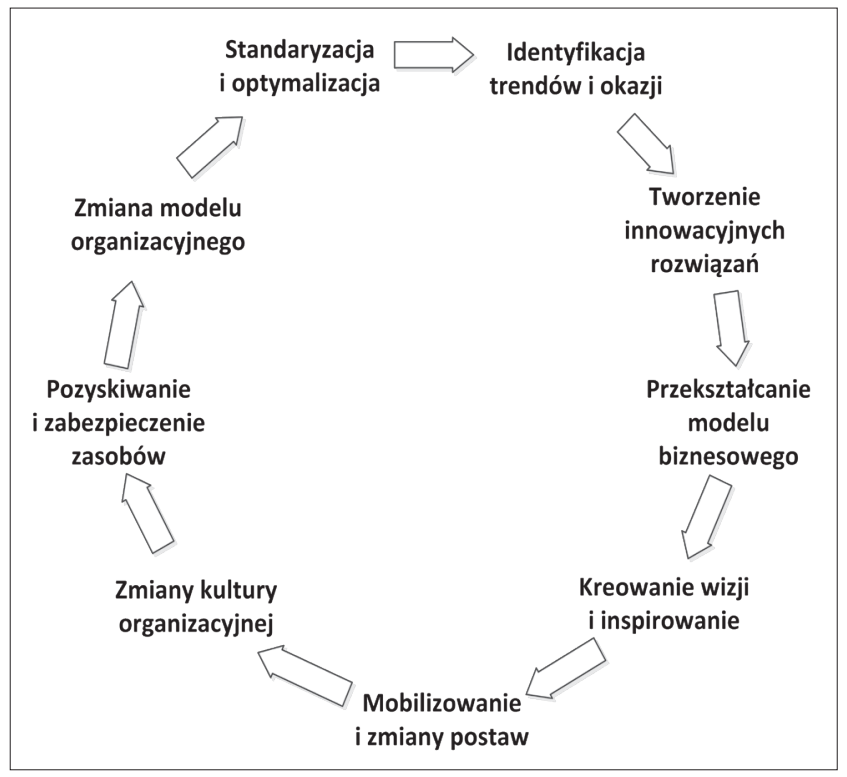

Rysunek 2. Składowe procesu odnowy przedsiębiorstwa

Źródło: opracowanie własne na podstawie [Cyfert, Krzakiewicz 2015 (artykuł w niniejszym zbiorze)].
Poszczególne składowe powyższego procesu zostały szczegółowiej opisane w stanowiącym część tego numeru prac naukowych artykule Sz. Cyferta i K. Krzakiewicza „Model procesu odnowy organizacyjnej”. W dalszej części niniejszego artykułu, prezentując wyniki przeprowadzonych badań, odniesiemy się do znaczenia oraz specyfiki tychże składowych.

\section{Potencjał odnowy przedsiębiorstw}

Badanie procesów odnowy przedsiębiorstw wymaga rozumienia ich źródeł, elementów składowych oraz pomiędzy nimi powiązań. Pełne rozumienie istoty prowadzi jednak zawsze do pytania o to, co powoduje, że organizacje są w stanie we właściwym czasie zainicjować takie procesy, właściwie zinterpretować często słabe sygnały $\mathrm{z}$ otoczenia, a następnie poprzez innowacje wypracować nowy model biznesowy, przebudować swoje organizacje i dokonać faktycznej odnowy. Badania R. Gulatiego, N. Nohrii i F. Wohlgezogena w dobitny sposób zwracają uwagę na skalę wyzwań, jakie stanowi zdolność skutecznej odnowy dla przedsiębiorstw na przestrzeni wielkich kryzysów zachodzących w trzech ostatnich dekadach. Opierając się na longituidalnych studiach uwzględniających próbę niemalże 
5 tys. przedsiębiorstw, zauważyli oni, iż jedynie 9\% przedsiębiorstw zdołało wyjść z okresów globalnych recesji w lepszej kondycji, mierzonej przynajmniej 10-procentowym szybszym wzrostem sprzedaży i zysków niż średnia w branży, w jakiej funkcjonowały [Gulati, Nohria, Wohlgezogen 2010]. W ostatnim czasie A. Binns, J.B. Harreld, Ch.A. O’Reilly oraz M.L. Tushman zwracają uwagę, że analiza przypadków firm takich jak Kodak, Nokia czy BlackBerry nieustannie zmusza do poszukiwania źródeł zdolności odnowy strategicznej przedsiębiorstw [Binns et al. 2014].

W studiach nad tym zagadnieniem ślady poszukiwań mechanizmów kształtujących potencjał odnowy można znaleźć w światowej literaturze przedmiotu od ponad dwóch dekad. M. Hammer, opisując strukturę mechanizmów warunkujących zdolność systemu do odnowy i przeobrażeń, rozróżnił dwa systemy zarządzania funkcjonujące $w$ organizacji. Pierwszy z nich określił jako powierzchniowy (surface system), drugi natomiast jako głęboki (deep system). System powierzchniowy odniósł do tworzących wartość procesów, systemów, struktur i wartości. Za istotę systemu głębokiego uznał z kolei rozpoznawanie zmian, jakie zachodzą $\mathrm{w}$ otoczeniu, analizowanie tych zmian oraz oddziaływanie na dostosowywanie się syste$\mathrm{mu}$ powierzchniowego. System głęboki wyraża zdaniem M. Hammera zdolność organizacji do zmian [Hammer 1996, s. 215]. Wśród koncepcji powstałych w latach dziewięćdziesiątych przytoczyć można choćby propozycje S. Ghoshala i Ch. Bartletta, opisujące model i behawioralny kontekst odnowy [Ghoshal, Bartlett 1996] oraz S. Meziasa i M. Glynn, badających formy odnowy z perspektywy procesów innowacyjnych [Mezias, Glynn 1993]. W pierwszej dekadzie XXI wieku rozpowszechniła się koncepcja dynamicznego potencjału (dynamic capabilities), autorstwa D. Teece'a [2000, s. 5]. Wszyscy przytaczani autorzy przedstawiają propozycję strukturalizacji mechanizmów kształtujących potencjał samoodnowy przedsiębiorstwa, niezależnie od tego, jak definiują same te mechanizmy.

G. Bełz powiązał analizę powyższych koncepcji z pracami nad archetypowymi rolami menedżerskimi prowadzonymi m.in. przez J. Kottera, B. Czarniawską i R. Wolffa oraz A. Mayo i N. Nohrię, proponując koncepcję triumwiratu ról zarządczych (zob. [Bełz 2011]). Triumwirat ról zarządczych można zdefiniować jako zjawisko polegające na tym, iż funkcje zarządcze realizowane są w każdej organizacji poprzez współistnienie odmiennych archetypowych ról: przedsiębiorcy, przywódcy i menedżera. Każdy z archetypów jest odmiennym profilem działań zarządczych, koncentrującym się na innych zadaniach, kluczowych dla przetrwania, funkcjonowania i rozwoju przedsiębiorstwa. Archetyp przedsiębiorczy odpowiada za zdolność przedsiębiorstwa do kreowania innowacyjnych rozwiązań, redefiniowania istoty swojego biznesu oraz uchwycenia pojawiających się okazji i unikania zagrożeń. Archetyp przywódczy warunkuje wykorzystanie potencjału pracowników w koniecznych procesach przemian poprzez budowanie tożsamości organizacji, a także wysokiej motywacji i zaangażowania ludzi. Archetyp menedżerski odpowiada natomiast za zapewnienie sprawności operacyjnej oraz bieżącą optymalizację, a także obniżanie kosztów transakcyjnych. Syntetyczne wyszczególnienie wyróżniających cech tych trzech archetypowych ról zarządczych prezentuje tab. 1 .
Tabela 1. Charakterystyka archetypowych ról zarządczych

\begin{tabular}{c|l}
\hline \multicolumn{1}{c|}{ Archetyp } & \multicolumn{1}{c}{ Charakterystyka } \\
\hline Przedsiębiorczy & $\begin{array}{l}\text { Innowacyjny, promujący i wdrażający innowacje, } \\
\text { skoncentrowany na pojawiających się okazjach } \\
\text { i możliwych efektach biznesowych, określający } \\
\text { nowe wizje przyszłości nierzadko sprzeczne } \\
\text { z obecnie uznawanymi }\end{array}$ \\
\hline Przywódczy & $\begin{array}{l}\text { Kształtujący poczucie tożsamości i wspólnoty, } \\
\text { skuteczny we wpływaniu i kształtowaniu przekonań } \\
\text { i postaw ludzi, inspirujący i motywujący ludzi do } \\
\text { osiągnięcia wyznaczanych przez niego celów }\end{array}$ \\
\hline Menedżerski & $\begin{array}{l}\text { Dobry organizator, poszukujący sposobów } \\
\text { i rozwiązań podnoszących efektywność, } \\
\text { standaryzujący i formalizujący pracę, uzyskujący } \\
\text { wyniki dzięki implementacji najlepszych praktyk }\end{array}$ \\
\hline
\end{tabular}

Źródło: opracowanie własne.

W ostatnim czasie na znaczenie takiego postrzegania organizacji zwrócili uwagę P. Dover i U. Dierk, którzy w badaniach nad innowacyjnością i oburęcznością organizacji stwierdzili, że menedżerowie, przedsiębiorcy i liderzy wnoszą do organizacji odmienne umiejętności i zdolności, podsumowując istotę każdego z archetypów poprzez koncentrację na [Dover, Dierk 2012]:

- bieżącej złożoności organizacji (menedżer),

- zmianie (lider),

- okazjach i innowacjach (przedsiębiorca).

Obok podejścia podmiotowego opartego na archetypowych rolach zarządczych w literaturze przedmiotu zauważalne jest także podejście przedmiotowe, koncentrujące się na identyfikacji kluczowych procesów odpowiedzialnych za zdolność organizacji do dostosowywania się i odnowy. Przytoczone na wstępie tego rozdziału koncepcje M. Hammera (procesy: uczenia się, przeprojektowywania oraz zmiany) oraz S. Ghoshala i Ch. Bartletta (procesy: uproszczenia, integracji i regeneracji) są jego najlepszym przykładem. Na podstawie porównania i krytycznej analizy tego typu propozycji G. Bełz [2011] zaproponował, aby za takie kluczowe procesy dostosowawcze uznawać procesy:

a) innowacji i inicjacji,

b) transformacji i integracji,

c) optymalizacji i standaryzacji.

Pierwszy z powyższych - proces innowacji i inicjacji - związany jest ze specyficznym postrzeganiem organizacji i jej otoczenia, które skupia się na wychwytywaniu, często słabych, bodźców sygnalizujących pojawianie się okazji zrobienia czegoś nowego i/lub w sposób odmienny od dotychczasowych. Charakterystyczne jest dla niego także kojarzenie kompetencji, służące uzyskiwaniu dodatkowych efektów dla organizacji. Proces ten ma również tę cechę, iż w powyższych dążeniach nie poddaje się ograniczeniom wynikającym z poziomu dostępnych zasobów czy też potencjału obecnego modelu organizacyjnego. Jest to proces „energetyzujący” organizację, generujący innowacje, stawiający wysokie wyzwania, ale i burzący dotychczasowy ład. 
Proces drugi - transformacji i integracji - opiera się na dynamice relacji międzyludzkich oraz leżących u ich podstaw potrzeb, dążeń i obaw. Jest wyrazem przeświadczenia, że poprzez potencjał tkwiący $w$ ludziach i łączące ich relacje możliwe jest osiągnięcie każdego wyobrażalnego celu. Proces ten nie jest tak intensywnie jak poprzedni zwrócony na zewnątrz organizacji, lecz wprost przeciwnie - skierowany ku jej wnętrzu. Jego charakterystycznymi cechami są kształtowanie, propagowanie, uzyskiwanie powszechnej akceptacji, a następnie odwoływanie się do integrujących całą zbiorowość wartości, zasad i celów. Oprócz budowania poczucia wspólnoty służy on aktywizowaniu ludzi do przyjmowania nowych postaw i zachowań, niezbędnych do zainicjowania i powodzenia trwałej zmiany.

Proces trzeci - optymalizacji i standaryzacji - wnosi ostatnią, nie mniej ważną perspektywę postrzegania organizacji, opierającą się na przeświadczeniu o znaczeniu porządku i ładu dla skutecznego funkcjonowania wszelkich rzeczy, w tym organizacji. Ład i zorganizowanie odnoszą się do wszelkich zasobów, a więc również ludzkich. W rzeczywistości gospodarczej ład oznacza także właściwe relacje pomiędzy kosztami wszystkich zasobów a dostarczanymi przez nie efektami, co przekłada się na racjonalność kosztową i wydajnościową. Cechami charakterystycznymi wynikającymi $\mathrm{z}$ powyższego nastawienia są: strukturyzowanie, aby ład tworzyć, optymalizowanie, aby go pogłębiać, i standaryzowanie, aby zaprowadzać i utrwalać porządek.

Trzy powyższe procesy są spójne $\mathrm{z}$ archetypowymi rolami triumwiratu zarządczego $\mathrm{w}$ takim sensie, iż można wskazać wzajemne ich dopasowanie. Prezentuje je tab. 2 :

Tabela 2.Procesy i archetypy składające się na potencjał dostosowawczy

\begin{tabular}{l|l}
\hline \multicolumn{1}{c|}{ Archetyp } & \multicolumn{1}{c}{ Proces } \\
\hline przedsiębiorczy & innowacji i inicjacji \\
\hline przywódczy & transformacji i integracji \\
\hline menedżerski & optymalizacji i standaryzacji \\
\hline
\end{tabular}

Źródło: opracowanie własne.

Wskazane powyżej archetypy zarządcze oraz procesy dostosowawcze kształtują potencjał dostosowawczy organizacji. Jest on cechą umożliwiającą określenie stopnia, w jakim organizacja może sprawnie inicjować i regulować procesy gruntownej transformacji przedsiębiorstw. Jeśli powiązać takie ujęcie z zaprezentowanym $\mathrm{w}$ poprzednim rozdziale procesem odnowy, możliwa staje się próba zdefiniowania procesowego modelu odnowy przedsiębiorstwa. W naszej propozycji proces odnowy warunkowany jest potencjałem dostosowawczym organizacji. Ogólny schemat procesowego modelu odnowy przedsiębiorstwa prezentuje rys. 3 .

Zastosowanie powyższego modelu pozwala na głębszą interpretację i diagnozę zarówno ogólnego potencjału odnowy przedsiębiorstwa, jak i zachodzącego w danym czasie procesu odnowy. Można wskazać powiązania przyczynowo-skutkowe pomiędzy poszczególnymi elementami potencjału dostosowawczego a składowymi procesu odnowy, choć przyjmujemy,

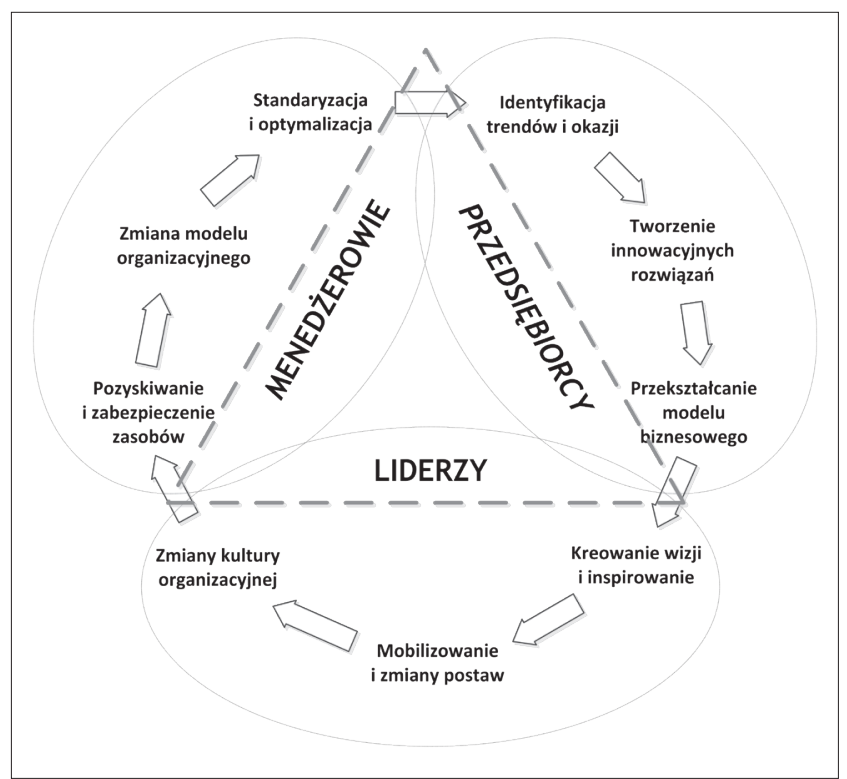

Rysunek 3. Procesowy model odnowy przedsiębiorstwa

Źródło: opracowanie własne.

że zakładanie jednoznacznych i trwałych powiązań w tym zakresie może stanowić zbyt duże uproszczenie. Poniżej, opierając się na wynikach badań, wskażemy możliwości interpretacji wynikające $\mathrm{z}$ zastosowania modelu.

\section{Kluczowe składowe procesu odnowy w świetle badań}

W ramach realizacji projektu badawczego „Odnowa organizacyjna polskich przedsiębiorstw" przeprowadzone zostało postępowanie badawcze koncentrujące się na identyfikacji przyczyn oraz kluczowych działań w procesach odnowy polskich przedsiębiorstw. Opierało się ono na badaniach ankietowych, a proces składał się z dwóch podstawowych etapów. W pierwszym etapie do 500 przedsiębiorstw skierowane zostały ankiety, których konstrukcja odpowiadała założeniom modelowym oraz teoretycznym przyjętym w pierwszej fazie badań. W tym kroku latem 2013 roku uzyskano 146 zwrotnych ankiet, którą to próbę po weryfikacji zawężono do 126. Weryfikacje wskazań z ankiet pierwszego etapu skłoniły zespół do zawężenia pola badawczego oraz ograniczenia skali możliwych odpowiedzi.

Drugi etap badań ankietowych przeprowadzony został w okresie październik 2013 - kwiecień 2014. W jego wyniku uzyskano ostatecznie 347 wypełnionych i pozytywnie zweryfikowanych ankiet. W połączeniu z danymi uzyskanymi w pierwszym etapie, dało to łącznie 473 poprawnie wypełnione ankiety.

Podmiotem badania były przedsiębiorstwa funkcjonujące na terenie Polski. W uzyskanej próbie badawczej 258 przedsiębiorstw (54\%) zadeklarowało, iż stanowi własność jedynie polskich właścicieli, natomiast 215 (46\%) to przedsiębiorstwa z udziałem kapitału zagranicznego. W próbie badawczej dominującą grupę stanowi 189 przedsiębiorstw (40\%) średniej pod względem liczby pracowników wielkości (tzn. zatrudniających 
50-249 osób). 155 przedsiębiorstw (33\%) należy zaliczyć do grupy firm małych (tzn. zatrudniających 10-49 osób). Najmniej liczną grupę, choć nadreprezentowaną w porównaniu ze statystyczną strukturą przedsiębiorstw w Polsce, stanowi 129 (27\%) przedsiębiorstw dużych (tzn. zatrudniających powyżej 250 osób).

Realizowane w badaniu identyfikowanie czynników efektywności procesów odnowy dotyczyło zarówno przesłanek podjęcia procesu odnowy, jak i sposobów jego realizacji. Analiza przeprowadzona w pierwszym etapie badań ilościowych wykazała, że dane z metryczki ankiety nie były różnicujące, gdyż nie stwierdzono zależności pomiędzy takimi cechami, jak: rodzaj zainwestowanego kapitału, wielkość zatrudnienia czy poziom przychodu a wpływem którejkolwiek z tych cech na uzyskiwanie przez badane przedsiębiorstwa wyższego poziomu efektywności.

Brak takiej „prostej” zależności zakładany był już na wstępnym etapie badań. Zespół badawczy zakładał, iż analogicznie do ogólnie rozumianego zjawiska zmian organizacyjnych, efektywność procesów odnowy przedsiębiorstw zależna jest w bardziej złożony sposób od różnorodnych czynników tkwiących po stronie przesłanek i warunków odnowy (treść), a także od samego jej przebiegu (proces). Dane uzyskiwane z badań ankietowych należy w większości uznać za zmienne skategoryzowane, co prowadziło do zastosowania w ich analizie testów chi-kwadrat, a jedynie w części przypadków wystąpiła możliwość badania zależności pomiędzy zmiennymi z wykorzystaniem, jako adekwatnego, współczynnika korelacji.

W niniejszym artykule, zgodnie z jego tematyką, odnosimy się jedynie do zagadnień związanych z badaniem samego procesu odnowy. Aby ten cel osiągnąć, prowadzonym analizom poddano czas oraz natężenie realizacji składowych procesu odnowy. Weryfikacja statystyczna sprowadzała się tu do badania, czy i na ile czas oraz natężenie realizacji poszczególnych składowych procesu odnowy mogą przekładać się na jego efektywność. Syntetyczne zestawienie wyników w tym zakresie dla dziewięciu składowych procesu odnowy prezentuje tab. 3 .

Przedstawione dane w odniesieniu do czasu oddziaływania składowych procesu wskazują, iż każda z nich, dla zapewnienia efektywności procesu odnowy, wymaga istotnego zaangażowania czasu ze strony liderów organizacji. W ramach pozy- skiwania do idei i przeprowadzania procesu odnowy, a także zmieniania postaw pracowniczych (składowa 5) skuteczne transformacje wiążą się z realizacją działań w tym zakresie na przestrzeni większości czasu, w jakim przeprowadzana jest odnowa.

Uzyskane dane w odniesieniu do natężenia procesu odnowy wskazują bardziej zróżnicowany obraz. Wysokie natężenie działań z zakresu identyfikacji trendów i okazji w otoczeniu (składowa 1), jak również mobilizowania i zmian postaw pracowników (składowa 5) identyfikowane są jako niezbędne dla powodzenia odnowy. Większość z pozostałych składowych dla efektywności odnowy wymaga co najmniej średniego natężenia. Jednak w odniesieniu do dwóch składowych: przekształcania modelu biznesowego oraz zmian kultury organizacyjnej nie stwierdzono takiej prawidłowości. Głębsza analiza uzyskiwanych odpowiedzi skłania do przyjęcia interpretacji, według której te dwie, ostatnio wymienione składowe procesu odnowy nie są uznawane, jako istotne przez respondentów. Wskazuje to, naszym zdaniem, na możliwość występowania ciekawego zjawiska, związanego z dużą dozą działań akcyjnych, na jakich opierają się analizowane przez nas przypadki odnowy.

Interpretując uzyskane dane z perspektywy zaproponowanego, procesowego modelu odnowy przedsiębiorstwa, warto zwrócić uwagę, że za kluczowe składowe respondenci uznają identyfikację trendów i okazji w otoczeniu oraz mobilizowanie i zmiany postaw pracowników. Co ciekawe, nie wskazują żadnego z działań, jakie można przypisać do perspektywy menedżerskiej. Równocześnie za nieistotne dla powodzenia procesów odnowy uznają przekształcanie modelu biznesowego oraz zmiany kultury organizacyjnej. Taka interpretacja uzyskanych wyników prowadzi, naszym zdaniem, do dwóch podstawowych wniosków. Po pierwsze, za kluczowe dla powodzenia zmian badane przedsiębiorstwa uważają zdolność do wychwytywania okazji w otoczeniu oraz budowanie i utrzymywanie wysokiej energii poprzez intensywne motywowanie i pozyskiwanie pracowników. Zauważają więc znaczenie składowych odnoszących się do pojedynczych działań przedsiębiorczych oraz przywódczych, nie uznając konieczności zbudowania odpowiedniej intensywności działań menedżerskich. Po drugie, niskie oceny wpływu na efektywność zmian uzyskują w badanej grupie składowe, które można kojarzyć z systemowym, kompleksowym podejściem do zarządzania organizacją.

Tabela 3. Zależność pomiędzy czasem i natężeniem a efektywnością odnowy

\begin{tabular}{l|l|l}
\hline \multicolumn{1}{c|}{ Składowa procesu } & \multicolumn{1}{c}{ Czas } & \multicolumn{1}{c}{ Natężenie } \\
\hline 1. Identyfikacja trendów i okazji & do połowy & wysokie \\
\hline 2. Tworzenie innowacyjnych rozwiązań & do połowy & średnie \\
\hline 3. Przekształcanie modelu biznesowego & do połowy & brak zależności \\
\hline 4. Kreowanie wizji i inspirowanie & do połowy & średnie \\
\hline 5. Mobilizowanie i zmiany postaw & większość & wysokie \\
\hline 6. Zmiany kultury organizacyjnej & do połowy & brak zależności \\
\hline 7. Pozyskiwanie i zabezpieczenie zasobów & do połowy & średnie \\
\hline 8. Zmiana modelu organizacyjnego & do połowy & średnie \\
\hline 9. Standaryzacja i optymalizacja & do połowy & średnie \\
\hline
\end{tabular}

Źródło: opracowanie własne. 
Ich przykładami mogą być: przekształcanie modelu biznesowego, kreowanie wizji i inspirowanie, pozyskiwanie i zabezpieczenie zasobów, zmiana modelu organizacyjnego oraz standaryzacja i optymalizacja. Wskazuje to na duże znaczenie adhokracji w przeprowadzaniu złożonych procesów transformacji. Może być ona spowodowana zarówno brakiem odpowiednich kompetencji w populacji polskich menedżerów, jak i przywiązaniem do działań akcyjnych. Wnioski takie wzmacniają wyniki przeprowadzonych studiów przypadków, wskazujące na słabości zwłaszcza w zakresie systemowego podejścia do realizowanych procesów i opierania się na standaryzacji oraz aktywizacji postaw przywódczych na średnich i niższych szczeblach zarządzania.

\section{Podsumowanie}

Celem artykułu było przedstawienie procesowego modelu odnowy przedsiębiorstwa i zidentyfikowanie za jego pomocą kluczowych cech warunkujących efektywność procesów odnowy. Przeprowadzone studia literatury przedmiotu oraz prace badawcze realizowane w ramach projektu „Odnowa organizacyjna polskich przedsiębiorstw" pozwoliły na uporządkowanie propozycji definiowania kluczowych zjawisk i składowych procesu odnowy. W ramach zrealizowanych studiów zaproponowano ich powiązanie z potencjałem dostosowawczym organizacji opartym na potencjale dostosowawczym. Analiza danych ilościowych uzyskanych od niemalże pięciuset przedsiębiorstw pozwoliła na identyfikację i interpretację składowych o kluczowym znaczeniu dla powodzenia procesu odnowy.

Uzyskane dane umożliwiły wyprowadzenie dwóch podstawowych wniosków. Po pierwsze, za kluczowe dla powodzenia zmian badane przedsiębiorstwa uważają zdolność do wychwytywania okazji w otoczeniu oraz budowanie i utrzymywanie wysokiej energii poprzez intensywne motywowanie i pozyskiwanie pracowników. Zauważają więc znaczenie składowych odnoszących się do pojedynczych działań przedsiębiorczych oraz przywódczych, nie uznając konieczności zbudowania odpowiedniej intensywności działań menedżerskich. Po drugie, niskie oceny wpływu na efektywność zmian uzyskują w badanej grupie składowe, które można kojarzyć z systemowym, kompleksowym podejściem do zarządzania organizacją

Uzyskane wyniki nie mogą oczywiście być uznawane za reprezentatywne dla przedsiębiorstw funkcjonujących w Polsce. Nie są również reprezentatywne dla trzech regionów, w których badane przedsiębiorstwa funkcjonują. Stanowią one raczej pierwszy krok na drodze do rozpoznania praktyk odnowy polskich przedsiębiorstw.

\section{Literatura}

Agarwal R., Helfat C., 2009, Strategic renewal of organizations, Organization Science, vol. 20, no 2 (March-April), s. 281-293.

Bełz G., 2012, Potencjał dostosowawczy w procesach odnowy przedsiębiorstw, Przegląd Organizacji, nr 11, s. 19-22.
Bełz G., 2011, System zarządzania jako regulator odnowy $i$ wzrostu przedsiębiorstw, Prace Naukowe Uniwersytetu Ekonomicznego we Wrocławiu, nr 153.

Bełz G., Olejczyk Z., 2012, Kształtowanie potencjału samoodnowy przedsiębiorstw, Sz. Cyfert, G. Bełz (red.), Prace Naukowe Uniwersytetu Ekonomicznego we Wrocławiu nr 276, s. 130-143.

Binns A., Harreld J.B., O’Reilly Ch.A., Tushman M.L., 2014, The art of strategic renewal, MIT Sloan Management Review, 55, no 2 (Winter), s. 21-23.

Cyfert Sz., 2012, Systemowy model organizacji: perspektywa procesów odnowy organizacyjnej, Prace Naukowe Uniwersytetu Ekonomicznego we Wrocławiu, nr 276, s. 123-129.

Cyfert Sz., Bełz G., Wawrzynek Ł., 2014, Wpływ burzliwości otoczenia na efektywność procesów odnowy organizacyjnej, Organizacja i Kierowanie, $\mathrm{nr} 1 \mathrm{~A}$ (159), s. 15-26.

Cyfert Sz., Krzakiewicz K., 2015, Model procesu odnowy organizacyjnej, Management Forum nr 1(6), Prace Naukowe Uniwersytetu Ekonomicznego we Wrocławiu (w niniejszym zbiorze).

Czarniawska-Joerges B., Wolff R., 1991, Leaders, managers, entrepreneurs on and off the organizational stage, Organization Studies, vol. 12 , no 4 , s. 529-546.

Dover P.A., Dierk U., 2012, The ambidextrous organization: Integrating managers, entrepreneurs and leaders, Journal of Business Strategy, vol. 31, no 5, s. 49-58.

Ghoshal S., Bartlett Ch., 1995, Building the entrepreneurial corporation: New organizational processes, new managerial tasks, European Management Journal, vol. 13, no 2 (June), s. 139-155.

Ghoshal S., Bartlett Ch., 1996, Rebuilding behavioral context: A blueprint for corporate renewal, Sloan Management Review, vol. 37, no 2 (Winter), s. 23-36.

Gulati R., Nohria N., Wohlgezogen F., 2010, Roaring out of recession, Harvard Business Review, March, s. 63-69.

Gupta V., MacMillan I., Surie G., 2004, Entrepreneurial leadership: Developing and measuring a cross-cultural construct, Journal of Business Venturing, vol. 19, s. 241-260.

Hammer M., 1996, Beyond Reengineering. How the process-centered organization is changing our work and our lives, HarperCollins Publishers, Inc., New York.

Leavy B., 1997, Strategic renewal - Is disruptive revolution unavoidable?, Strategic Change, vol. 6, s. 283-298.

Malach-Pines A., Sadeh A., Dvir D., Yafe-Yanai O., 2002, Entrepreneurs and managers: Similar yet different, The International Journal of Organizational Analysis, vol. 10, no 2, s. 172-190.

Mayo A., Nohria N., 2005, Zeitgeist leadership, Harvard Business Review, vol. 83, no 10 (October), s. 45-60.

Mezias S., Glynn M.A., 1993, The three faces of corporate Renewal: Institution, revolution, and evolution, Strategic Management Journal, vol. 14, s. 77-101.

Osterwalder A., Pigneur Y., 2010, Business Model Generation, John Wiley \& Sons, Hoboken.

Skalik J., Bełz G., 2007, Istota systemu zarządzania w procesie kształtowania i rozwoju organizacji, [w:] Zmiana warunkiem sukcesu. Przeobrażenia systemów zarzq̨dzania przedsiębiorstw, Prace Naukowe AE Wrocław nr 1184, s. 17-26.

Teece D.J., 2009, Dynamic Capabilities \& Strategic Management. Organizing for Innovation and Growth, Oxford University Press, New York.

Zaleznik A., 2004, Managers and leaders. Are they different?, Harvard Business Review, January, s. 74-81. 